risk for infection with non- $A$, non-B hepatitis.

of non-A, non-B hepatitis

The surrogate screening reduced the incidence of non- $A$, non- $B$ hepatitis by half, but roughly 200,000 people each year who receive blood transfusions in the United States are still exposed to the non-

- Elusive virus isolated after long search - Potential market for blood screening

\section{Washington}

THE search for the elusive viral agent responsible for non- $\mathrm{A}$, non-B hepatitis may be over. Last week, the California biotechnology company Chiron announced, to an accompaniment of stock trading activity, that its researchers had isolated and partially characterized the virus responsible for a large proportion of cases. The commercial prize is the sale of blood-screening diagnostic tests in the near term and of vaccines in the future.

The cause of blood-borne hepatitis cases not attributable to hepatitis- $B$ virus has been sought for more than 15 years. (Hepatitis A, or infectious hepatitis, is transmitted through contaminated food or water.) Although tests for the bloodborne hepatitis B were developed in the early 1970 s, until 1986 up to 10 per cent of transfusion recipients were still contracting hepatitis, presumably from infection by an unknown agent.

Because the virus, or viruses, responsible had not been identified, no specific test to screen transfusion blood has been available. Instead, since 1986 blood banks have used two surrogate tests, one for the presence of antibodies to hepatitisB core antigen, the other for elevated levels of alanine aminotransferase. Positive results on both tests correlate with

\title{
Conflicting views on the safety of US biological weapons
}

\section{Boston}

CONTROVERSY over the safety of US biological weapons programmes continued last week with the release of conflicting reports by the Pentagon and by the majority staff of a Senate oversight subcommittee.

The Pentagon assessment, which says the programmes do not imply adverse environmental or public health effects, stems from a 1986 lawsuit brought by Jeremy Rifkin's Foundation on Economic Trends. On the grounds that the military's conduct of its biological defence research involved "wholesale violations of the

\section{Fang Lizhi returns \\ London}

Dr Fang Lizhi, the astrophysicist who in January 1987 was dismissed from his post as vice chairman of China's University of Science and Technology and expelled from the Communist Party, has made an unofficial political comeback, addressing a gathering of students on the topics of human rights, democracy, economic reform and modernization.

Fang's political disgrace followed an address he gave to university students at the end of 1986, which, the party authorities alleged, had incited them to street demonstrations demanding greater intellectual freedom. On this occasion, Fang made it clear that he was not in favour of the students taking to the streets, but rather they should "keep quiet for a time".

Vera Rich
National Environmental Policy Act," Rifkin's group last year won a court settlement requiring the Pentagon to write an environmental impact statement, of which last week's report is the draft.

Citing many "mitigative measures, controls and monitoring", the Pentagon says its biological research shows that the perceived risks of the research programme are "very much exaggerated" and that even the unlikely event of a severe accident would not lead to "catastrophic results".

But Andrew Kimbrell, a lawyer for the Foundation for Economic Trends, called the Pentagon assessment "shoddy", "irresponsible" and "totally inadequate". He says that unless the report is substantially revised, the foundation will return to court seeking an injunction of the entire biological research programme.

The Senate report, timed to coincide with the Pentagon assessment, also differs sharply with it, stating that there are "increasing risks" and "serious failings" in the Defense Department's management of safety controls. These are said to include "inadequate regulations, lax safety enforcement and documented safety lapses".

Democratic Senator Carl Levin, chairman of the Senate Subcommittee on Oversight of Government Management, says that his subcommittee will hold hearings this summer on problems raised in the report and that it will also carry out its own review of the draft environmental impact statement.
Seth Shulman $A$, non-B hepatitis virus. Of these, half may go on to develop chronic hepatitis, and 20 per cent of the chronic carriers will eventually develop cirrhosis.

Chiron says it has been working on the problem for the past five years. Data suggesting that Chiron researchers may have isolated the virus responsible for the majority of non-A, non-B hepatitis cases were reported at a small symposium at the University of California at San Francisco on Monday last week. Chiron said that because of the commercial significance of the discovery, it held press conferences the next day to allow all its shareholders to have equal access to the information.

According to Michael Houghton, Chiron has cloned and expressed a protein from a virus that reacts with antibodies from over half of patients who have non$A$, non-B hepatitis. Houghton says the virus is a single-stranded RNA virus with a genome of approximately 10,000 nucleotides, which may be classed as a toga virus.

The virus has been difficult to study because it is found in very low concentrations in infected tissue, and only infects chimpanzees and humans. But Houghton's group has sequenced 30-40 per cent of the virus, and has expressed roughly 10 per cent of its coding potential through recombinant means. Houghton hopes to have his group's results published later this year.

The announcement last week spurred sales of Chiron stock, and drove the price per share up by 30 per cent at one point. Officials of the NASDAQ over-thecounter market froze trading of the stock temporarily on Tuesday last week because of the large volume of shares changing hands, suggesting that word had leaked out before the press conferences began.

Chiron has developed a prototype immunoassay for the new virus, and plans to apply for human trials before the end of 1988. The potential market for the diagnostic test in blood-screening and clinical diagnosis is estimated at $\$ 85$ million a year. Chiron has licensed marketing rights for the immunoassay to Ortho Diagnostic Systems, a subsidiary of Johnson \& Johnson.

$A$ vaccine for non- $A$, non- $B$ hepatitis is still far off, but Chiron has formed (with Ciba-Geigy) the Biocine Corporation to market any that is developed. Chiron produced the first recombinant vaccine, for hepatitis B, now sold by Merck. Chiron has also applied for patents covering the expression of non- $A$, non- $B$ hepatitis virus proteins.

Carol Ezzell 